(C) 2017, Elsevier. Licensed under the Creative Commons Attribution-NonCommercial-NoDerivatives 4.0

International

http://creativecommons.org/licenses/by-nc-nd/4.0/

\title{
Value creation and capture through human resource management practices: Gazing
}

\section{through the business model lens}

\begin{abstract}
A business model refers to a firm's blueprint for creating and capturing value through a set of interlocking activities. This paper focuses on explicating, by utilising the resource-based view (RBV) theory, the key human resource management (HRM) practices that support firms' value creation and capture elements of a business model. We present a processual understanding of how several HRM practices differently support in value creation and capture processes. Employing an inductive approach via qualitative data analysis of ten case study organisations from the Indian IT /BPO industry, we found that the dominant business model focuses on efficient and differentiated services. From an HRM perspective, by developing client-centric values/culture, investing in a range of learning and development activities and following a control-oriented work design, value creation is possible. Further, the adoption of an industrial approach to training, focused hiring, process-focused HRM and project-based performance management support value capture. We conclude by highlighting the key implications of our findings for both theory and practice.
\end{abstract}

\section{Introduction}

Although the concept of business model has dominated the practitioner literature for nearly two decades, the increased academic interest in the concept is recent (e.g. Baden-Fuller \& Morgan, 2010; Baden-Fuller et al., 2013; Osterwalder \& Pigneur, 2005; Morris et al., 2005; Spieth et al., 2013; Zott et al., 2011). The literature on business model design and innovation tends to draw on several disciplines such as strategy, information systems and management (Spieth, Schneckenberg, \& Ricart, 2014) and its multivalent character has been the focus of recent special issues dedicated to the topic (e.g. Long Range Planning, 2010; 2013, International Journal of Innovation Management, 2013, Strategic Organization, 2013, and $R \& D$ Management, 2014). Whilst there have been several studies using the RBV theoretical lens to examine the link between HR strategy, HRM practices and firm performance (e.g. high performance work systems, high involvement management, high commitment management), there is limited research undertaken that delineates, using the RBV, HRM practices that create and realise value. Value creating HRM practices must be complemented by value realising HRM practices for delivering on a sustainable business model. There is little research undertaken on the value creating and value realising activity systems of HRM practices that support these key elements of a firm's business model. The emergent understanding of the concept suggests that researchers view it not only as an abstract model but also as a guiding framework for managerial cognition and action, informing managers' strategic choices (Baden-Fuller et al., 2013; Spieth et al., 2013; 2014). Business models specify the how and why behind managerial thought and actions (BadenFuller et al., 2013) or as Teece (2010) postulates, a business model is a firm's theory of how its product/services are created and delivered to meet the needs of its customers, in a way they want it, so that the firm can organise its resource architectures and value chain in a profitable way. 
Johnson et al.'s (2008) definition of business model is considered relevant for this paper, who suggested that 'a business model, from our point of view, consists of four interlocking elements that, taken together, create and deliver value" (p52). These include: core value proposition, key resources, processes and a profit formula. Zott et al. (2011) highlight the limitations in conceptualising business models is due to the lack of a common language and the theoretical lens that underpin the concept. Others have also argued that scholarship in this area is affected by the equivocal understanding and weak theoretical foundations of the concept (see Arend, 2013; O'Connor \& Yamin, 2011; Morris et al., 2005; Zott et al., 2011). Nevertheless, there is a growing consensus among researchers that business model concerns itself with value creation and capture activities in firms (Baden-Fuller \& Morgan, 2010; Baden-Fuller et al., 2013; Osterwalder, \& Pigneur, 2005; Spieth et al., 2013; Zott \& Amit, 2010). Attending to the above debates, scholars have subsequently identified areas where future research should be directed. These include: (1) adopting a holistic approach to analyse business models; (2) investigating the key activities and value chain components of a business model at a functional level; and (3) their effects on a firm's outcomes (Schnieder \& Spieth, 2013; Zott \& Amit, 2013). Spieth et al. (2014) propose a role-based approach that explains the business, as to how a business generates profit; understands the mechanisms and devices that support the running of a business, wherein, understanding the functional activities and practices that support the delivery of a business model; and finally, developing a business for current and future needs of a business, as a way to extend future research on business models. It is in the second identified gap (of functional HRM activities and practices) that this paper attempts to fill. Although there are several functional value-chain activities that one can focus on for example, marketing, production and human resources, this paper focuses exclusively on the various HRM activities that influence the value creation and capture processes of a firm's business model.

Others have noted that a firm's activity system focuses on how best to engage the firm's resources to purposively create and capture value (Zott \& Amit, 2010; Zott \& Amit, 2013). Thus, activities in such a business system are interdependent on the interactions between different elements that make up an activity system. These, include interdependencies such as a firm's internal and external stakeholders (e.g. employees, clients, and vendors) and its internal resources and capabilities that collectively shape in creating and realising value for the firm. Given managers and leaders are tasked with exercising strategic choices in the design and implementation of activities and systems that underpin a firm's business model, the extent to which the focal firm can create or capture value depends on such choices and tactical activities (Casadesus-Masanell \& Ricart, 2010). Thus, delineating the functional elements of a business model is a critical area for scholarship as it will help managers to better understand how they can create and capture value through such activities and the value chain (Schnieder \& Spieth, 2013).

In line with Zott and Amit (2013), our paper is an attempt to bridge the above presented research gap regarding the role of running a business, with a focus on its functional and value chain activities. More specifically, we focus on the role HRM practices play in the creation and capturing of value in a firm's business model. We analyse this gap in the context of India's global information technology (IT) industry. Our choice for this industry is based on the premise that firms in this sector have undergone several business model changes to deliver sustained levels of performance and growth, hence providing a dynamic 
research setting (e.g. Malik \& Rowley, 2015). Further, as organisations in the IT industry typify firms undergoing rapid technological and structural change and innovations, they are thus most suited to contemporaneously studying the phenomenon of business model and its elements at an activity and value-chain level (Malik, 2015; Zott \& Amit, 2013).

Over the past three decades or so, HRM scholars have adopted different approaches to unlock the relationship between strategic HRM practices, firm performance, and sustained competitive advantage (e.g. Becker \& Huselid, 2006; Delery \& Doty, 1996; Guest 2011; Pfeffer, 1998; Wright et al., 2001). More recently, Buller and Mclvoy (2012: 43) suggested the need for 'sharpening the line of sight' by linking human resources and strategy by identifying key HR practices that create and capture value, necessary for achieving sustained competitive advantage. We believe this deserves further granular explanation in order to not only address the performance linkages but also how HRM practices create and capture value. To date, to the best of our knowledge, barring a few studies (Lepak et al., 2007; Kang et al., 2007; Wright \& McMahan, 1992), strategic HRM studies have not explicitly attempted to explain how (and whether) certain HRM practices create and capture value for a firm's business model. By engaging in such a line of inquiry, we can make advances in 'sharpening the line of sight' argument (Buller \& Mclvoy, 2012: 43). While we acknowledge the contribution of several primary (operations, sales and marketing and logistics) and secondary (administration, technology and procurement) value-chain activities, this study contributes by 1 ) analysing the HRM practices that support value creation and realisation; and 2) showing how these practices contribute to the design and effective implementation of a firm's business model.

To this end, studying HRM practices that managers in the Indian IT industry design and implement is considered appropriate and timely. We tap into the evolving body of literature on various aspects of people management practices in the Indian IT and business process outsourcing (BPO) industry (Budhwar \& Bhatnagar, 2009; Budhwar \& Varma, 2011; Malik, 2009; 2013; Pereira \& Anderson, 2012) and attempt to answer the following research questions:

1. What are the key HRM practices that contribute to the key elements of value creation and value capture in a firm's business model?

2. How do certain HR practices create and capture value for a firm's business model?

While addressing the above mentioned research questions, our study contributes to the literature on business models and strategic HRM by (1) developing a conceptual model of linking HR practices to the commonly understood elements of a firm's business model; (2) identifying the key HRM practices that create and realise value; (3) grounding the discussion and analysis in a theoretical lens that is appropriate for integrating HRM practices with the business model concept; and (4) identifying the critical activities (HRM practices). This also helps to fill the identified gaps in business model literature and provide guidance for managers to objectively allocate their resources that create and realise value. The rest of the paper is organised as follows. We begin by reviewing the literature on business models and linking it to appropriate theoretical approaches relevant for this paper. Next, we outline the methodological and analytical approach employed for this research. This is followed by findings and discussion and implications for theory and practice. 


\section{Business models: Theoretical frames and functional activities}

The current, largely atheoretical and evolving state of business model research can be partly attributed to the conflicting definitions, conceptualisations, emphasis, and applications (see e.g. arguments made by Arend, 2013; Spieth et al., 2013; 2014; Zott, Amit \& Mossa, 2011) and partly due to its relatively recent interest in academic literature (Coombes \& Nicholson, 2013; Osterwalder \& Pigneur, 2005). Abdelkafi, Makhotin and Posselt (2013), for example, identified five distinctive elements in business models: value proposition, communicating the value, creating value, and delivering and realizing value. Similarly, Günzel and Holm (2013), employing Osterwalder and Pigneur's (2010) key elements of a 'business model canvas' argue that the focal firm must pay full attention to the front and back-end elements that variously help a firm create and capture value. Employing the metaphor of business models as a recipe, Baden-Fuller and Morgan (2010) highlight the importance of key ingredients such as the resources, capabilities, products, customers, technologies and so on in implementing business model design and innovation. Overall, business models underscore the creation, capture and realisation of value for an organisation's customers (Baden-Fuller \& Morgan, 2010; Johnson et al., 2008; Teece, 2010). Nevertheless, our analysis suggests that there are some common themes emerging in the literature on the content and process aspects of a business model. These include: (1) the link between business models, strategy and its tactics (Osterwalder \& Pigneur, 2002); (2) the strategictactical link is in generating value for the customers (Johnson et al., 2008); and (3) by adopting a role-based and functional activities perspective, we can develop better understanding of the processual aspects of business models. Casadesus-Masanell and Ricart (2010: 195) argue that a business model 'is a reflection of the firm's realised strategy' and that firms exercise strategic choices in deciding their business model. For example, in which market a firm wants to operate in and how must it deploy the tactics to support its choice. These choices cover a range of operational and functional activities throughout the firm's value chain.

\section{Theoretical frameworks}

Schnieder and Spieths' review (2013) highlights three theoretical lenses for analysing business models: resource-based view (RBV) (Barney, 1991; Wright et al., 2001), dynamic capabilities (Teece et al., 1997) and strategic entrepreneurship (Miller, 2003). We note that dynamic capabilities is a useful lens as it focuses on how a firm must develop and manage its current capabilities portfolio to continue to create and realise value in a dynamic and volatile technological environment. The third theoretical lens helps in furthering our understanding of how leaders and managers in firms explore and exploit market opportunities. Zott and Amit (2013) have argued that business models have to focus on exploitation to create value and efficiencies in an organisation's production function, a view that is deeply anchored in transaction cost economics literature, whereas, firms focusing on exploration or innovation, would find the notion of dynamic and complementary capabilities useful for locking-in value from a firm's networks.

For the purposes of this study, we consider the RBV perspective as highly relevant because it provides a framework for analysing the HRM practices, resources and capabilities that matter most in creating and capturing value for sustained competitive advantage. Extending their support for the RBV, Lepak, Smith and Taylor (2007) and Priem (2007) highlight that a firms resources and capabilities must be valuable and rare for the value creating source (for 
example, the organisation) and its target (for example, its users of services/products). Further, Priem (2007) highlights that a firm's resources must strive to create and increase value for its customers much before they seek to capture such value, a view consistent with Ethiraj et al.'s (2005) findings of building client-specific capabilities in the Indian IT sector. While the first two elements of RBV - value and rarity of resources and capabilities are critical in value creation, the other two elements of RBV, i.e., inimitability and organisation of resources are central to capture value (Lepak et al. 2007). Lepak et al. note that a firm's ability to capture or realise value is dependent on how well it creates isolating mechanisms or barriers to prevent imitation of value thus created, to prevent, in a competitive market, profits and advantage positions to be shaved away. Priem (2007) suggests that firms must develop and synchronise processes to support creation and extraction of value from its resource portfolio. Hence, unique and novel approaches to managing the resource portfolio is vital for value capture.

\section{Functional activities}

In a similar vein, Zott and Amit (2013) argue that by adopting an activity approach, we can identify the activities that are fitting and internally (horizontally) and strategically (vertically) consistent. Lepak et al. (2007) and Zott and Amit (2013), in a Porterian (1985) sense, note the importance of secondary value-chain activities (such as HRM practices) in supporting the performance of primary activities (such as sales and operations), and found that by organising new ways of managing work, innovations and business processes, firms can create value. Similarly, by developing unique social networks and specialist skills and processes, value capture is possible. Wright and McMahan (1992) have argued for developing skills and creating a motivational environment for value creation. Along the same premise and applying the RBV logic, Boxall (1998) has argued that a firm's human resource advantage is a function of the investments in its human capital portfolio to create both human capital advantages as well as organisational process advantage by focusing on creating hard to imitate processes. Malik and Rowley (2015) map business model evolution in the Indian IT industry from body-shopping and onsite models through offshore and global delivery models to a crowd and cloud-based business model; highlighting the links between Johnson et al.'s business model elements (core value proposition, resources, processes and profit formula) and HRM practices. Analysing the contributions in their collection, Malik and Rowley (2015) argue that Indian IT firms have successfully overcome the barriers of access to markets, resources, timely delivery, and skills by investing in HRM practices such as training, talent acquisition, value-stream mapping, job re-design, employee socialisation and collaboration, rewards, hiring, employee turnover, quality management capabilities and performance management. In a study of four Indian BPO organisations, Malik et al. (2012) found that BPO firms employ quality management accreditations and practices for not just market signalling purposes, but also for identifying the expressed and latent needs of their clients. Further, the quality management capabilities of these firms enabled identification of critical to performance metrics of their clients and aspects of service delivery that are doable using the extensive data analysis, collected during servicing multiple clients. Although this work provides a useful starting framework for analysing the linkages between HRM practices and business model elements, it does not demarcate between the value creation and value capturing HRM practices and how these practices interact with other HRM practices in supporting a firm's business model. We find Lepak et al.'s (2007) work on delineation of HRM activities for creating and realising value useful. 


\section{METHODOLOGY}

Considering the exploratory nature of our research, we adopted an inductive approach to our investigation (as proposed by Eisenhardt, 1989). Semi-structured interviews were conducted with 80 employees, $\mathrm{HR}$ and training managers, $\mathrm{CEO} / \mathrm{COO}$, business development, and quality management in 10 case organisations (see Tables 1 and 2 for details). Additional secondary data from the public domain, organisational documents and policies, and nonparticipant observations was also analysed. On average, the interviews ranged from 60 to 120 minutes and were transcribed verbatim. Unstructured automated analysis of interview data of 475 pages of transcripts (or 212,703 words) was undertaken using Leximancer- 4, a specialist content analysis software. Leximancer 4 allows for an automated mining of key concepts in a data set through non-linear dynamics, statistical algorithms, machine learning and statistical processes (Grech et al., 2002; Smith \& Humphreys, 2006). This software application for qualitative data analysis relies on scientifically validated mathematical algorithms (Metropolis, Rosenbluth, Rosenbluth, Teller and Teller 1953). The back-end engine of this software focuses on two key aspects: (i) the frequency counts of key text and its co-occurrence in a two-sentence text block, which leads to the identification of concepts and key themes in a data set; and (ii) these concepts and themes are depicted through maps (Smith \& Humphreys, 2006).

The semantic and relational co-occurrence employed by the software application is backed by statistical rigour and it helps to reduce the researchers' bias that is typically associated with manual coding in most qualitative studies (Leximancer 2009; Smith 2003). The developers of this application have established the face validity, stability, reproducibility and functional and correlational validity of this software (Smith \& Humphreys, 2006). Such an approach is increasingly gaining importance in applied disciplines such as HRM and marketing management (Dann, 2010), international business (Liesch et al., 2011) and psychology (Cretchley et al., 2010)

\section{ANALYSIS AND FINDINGS}

Following the automated extraction of concepts and themes, a guided analysis of other subconstructs and themes was undertaken using visual maps, textual exploration and frequency hierarchies that are relevant for our analysis. The key auto-generated themes include: people, process, work, level, client, training, manager, project, product, company and market (see visual map in Figure 1).

\section{INSERT FIGURE 1 ABOUT HERE}

A more targeted theoretical coding followed using abductive logic, which involved an iterative process of using the automated concepts and themes and linking these back to literature on value creation and realisation in business models as well as HRM practices (Van Maanen, Sørensen, \& Mitchell, 2007). Thus, by focussing on identifying key HRM practices that support value creation and realisation in a firm's business model, we identified the key first-order (seed concepts) and second-order concepts (HRM practices) and aggregate dimensions (value creation and capture) of a business model in the case study organisations (Gioa, Corley \& Hamilton, 2012). See figure 2 for data structure following the analysis. 


\section{INSERT FIGURE 2 ABOUT HERE}

\section{Value creation through HRM practices}

From an HRM perspective, our analysis suggests that firms in the Indian IT industry create value through three activities: client-centric values and culture, learning and development and work design.

\section{Client-centric values and culture}

The primacy of value creation for customers in the highly competitive global IT industry is understandable. Researchers (see Ethiraj et al., 2005; Malik, 2009) observe that developing client-specific capabilities by IT vendors is a key activity in IT firms. Although, offshoring and outsourcing of services to India was driven by time, cost and skills arbitrage, value creation would not have sustained in the long-term if firms did not pay attention to developing a culture of client-centric values such as meeting clients' expressed and latent needs, generating ongoing productivity gains, a total solutions approach and gaining their confidence and managing change. For each of the above core value propositions, HRM practices have contributed to varying degrees. For example, client-centric values culture, investments in training and development and a control-oriented team-based work design supported value creation (see Table 3 for examples of excerpts in this regard). Across the case organisations, the need to satisfy the clients' expressed and latent needs was a key focus. This meant that the firms needed to develop technical, process-, project- and domain-specific skills for creating value propositions for its clients. Additionally, we show the processes through which interactions between the concepts and themes occur in the wider institutional environment and the internal and external influences (see Figure 3).

\section{Learning and development}

While a client-centric set of values is essential, for creating value for IT clients the resources needed have to be skilled and proficient in a range of common and specialist knowledge areas. Training and development of resources supported knowledge development in areas such as technical knowledge of various aspects of software development, business process reengineering, and knowledge of clients' specific products, projects and processes. The diversity (technical and behavioural) of the types of knowledge and skills needed to be developed necessitated investment in a wide range of knowledge and skills training. This was particularly evident in the case of larger organisations who had invested significant sums of money and internal resources for imparting such training and knowledge.

\section{Work design}

These valuable resources were further enriched through work design, wherein an extensive emphasis was on process discipline, eliminating waste from the processes and projects by undertaking value-stream mapping and providing training on quality management approaches. More specifically, by organising resources around clients and industry specific accounts, the resource value and rarity was greatly enhanced as teams often shared knowledge within and across client groups and industries to generate knowledge efficiencies as well suggest continuous process/project improvisations for delivering on better value for clients. Additionally, firms undertook cross-functional work designs for proposing project/process-specific solutions using their team's collective technical and business expertise. Through use of quality management frameworks and process mapping 
value creation was strengthened. Examples of how firms undertook this are provided in table 3.

\section{Value capture through HRM practices}

The ability of firms to capture value and generate surplus/profit through HRM practices has been a topic of intense debate and recent research (e.g. Malik \& Rowley, 2015). IT firms have adopted different configurations of value creating and capturing HRM activities. In this study, we found four key HRM practices that collectively created isolating mechanisms for value capture. These practices were: efficient training, focused hiring, process-focussed HRM and project-based performance management. Below we provide further analysis and explanation on each.

\section{Efficient training}

Realising human resource advantage requires the dual presence of human capital and organisational process advantages (Boxall, 1998). Our analysis suggests that human capital advantage was significantly improved by providing high levels of training, especially by large IT firms. On average, the training time per new employee varied from 10 to 14 weeks. Depending on the nature of service line or technology, new hires received additional volume and diversity of training. Further, all the large IT majors invested significantly in quality management frameworks (e.g. ISO 9000, Six Sigma, CMM, PCMM, etc.), not just for improving their market signalling about their service quality to their existing and prospective customers, but also for the purposes of streamlining and standardising the software development and other work processes and infusing a strong process discipline amongst the large and relatively young population of engineers deployed on diverse projects across different time zones. The business routine that was of extreme value to the organisation and the clients was predictability of service delivery as per pre-agreed development standards and processes. An industrialised approach to training large numbers of graduates (up to $60 \%$ in the case of Organisations $A, E, F$ and $G$ ) resulted in training cost economies (both in scale and scope). The unitised cost of training was significantly reduced due to high levels of entry level hiring. Managing a young and relatively inexperienced workforce meant adopting an extremely disciplined approach to workflow control and management. This resulted in control-oriented work routines and processes to realise the value and profits for the firm. In addition to gaining efficiencies in training, firms also developed specialist domain and vertical skills.

\section{Focused hiring}

Organisations A, E, F and G had a disproportionate share of its workforce with less than four years of work experience. These case organisations employed between $50-70 \%$ of their workforce as new graduate hires. The industrialised approach to setting up corporate universities in these four firms and hiring recent graduates is not a coincidence. It is a very deliberate attempt by large IT players to capture value by keeping the costs of hiring down by investing in qualified but less experienced resources. The corporate universities served as bridging schools. In the words of Prithvi Shergill, the Head of HR at HCL Technologies, a very large Indian IT/BPO firm "...we do need to manage our cost of supply; given that this is $50 \%$ $60 \%$ of your profit and loss statement." (cited in Roy, 2013). To begin with, the workforce composition of large IT and BPO majors had strong similarities. Most large (and successful) IT services firms managed their human resources costs and profitability by 'managing the 
pyramid' costs (e.g. Global Legal, 2013; Malik, Sinha \& Blumenfeld, 2012). We found support for managing the pyramid approach to HRM. Further, with high annual wage inflation, managing the average cost of experienced resources, which increases by about $15-30 \%$ per annum became a key performance metric for HR and line managers (e.g. Global Legal, 2013). Managers were tasked with maintaining significant wage differences (of up to eight times, e.g. Roy, 2013) between the entry and middle level employees to efficiently 'manage the pyramid', and thus contribute to the firm's profitability. The following quote by a respondent explains this aspect.

There is support for the above HR strategy in a recent study by Credit Suisse, wherein the average salary of graduate engineers (even after being adjusted for inflation) has fallen in real terms in the last fifteen years (Sinha, 2013). Although supply-side economics can partially explain this fall, the evidence also supports this to be an artefact of deliberate strategic choices exercised by business leaders in large IT firms. Most large IT firms have increased their ability to hire at lower levels through sustained investments in process automation, quality management and learning and development capabilities; some have been able to hire even non-engineering graduates at significantly lesser costs (Sinha, 2013; Malik et al., 2012). This deliberate strategic intent is also reinforced by the president of NASSCOM (the industry's key association), "Higher pay for freshers [graduate engineers] is difficult, considering you have to spend at least a year in making them productive, with up to 22 weeks of full-time training" (cited in Roy, 2013). It can thus be deduced that in addition to a well-developed recruitment and selection system, an efficient training and development infrastructure is critical deriving value from graduate hiring of engineering and non-engineering graduates.

\section{Process-focussed HRM}

Another critical HRM approach to capture value was to organise the entire gamut of HRM practices based on quality management frameworks such as 'People-Capability Maturity Models'. Quality management capabilities have been noted to provide sustained levels of performance in the IT industry and impacts other primary activities such as sales and marketing (Malik et al., 2012). For each HRM activity starting with recruitment and training, the used of quality management frameworks enabled collection, analysis and dissemination of metrics of performance that were critical to quality. As with most offshoring and outsourcing drivers, cost and efficiency remain critical elements of the total customer value proposition. Our analysis further suggests the emergence of a quality-oriented HRM approach for training and development and deployment of resources. Such an approach typified the underpinning philosophy of a control-oriented work organisation in these firms. Underpinning such process-based approach were specific modules of learning and development. Relative to investing in popular quality management frameworks, some firms employed strong technology-based workflow performance monitoring tools with their internal pre-established performance metrics. The use of proprietary tools created a highly idiosyncratic, yet valuable and inimitable set of routines amongst these firms.

Organisations $A, E, F$ and $G$ invested in numerous quality management frameworks and adopted a quality focused performance management approach to allow for value creation and capture. 


\section{Project-specific performance management}

Owing to a dominant process-focused HRM approach, project- and process-level workflow was tightly controlled and frequently monitored. Further, performance metrics were collated and disseminated to project teams by client, geography and industry levels. Extensive reliance of quality frameworks led to generation of such performance data across service domains and industry sectors. For example, in voice processes, performance management and monitoring was a monthly activity, whereas in back-office and knowledge processes, it was built around clients' service level agreements with pre-agreed metrics. With the benefit of working with multiple clients in a given industry and service line leads to the establishment of industry benchmarks and time and effort estimation metrics, which are then used at the time of negotiation of clients' service level agreements. Although such an approach creates extensive pressures on employees, often leading to high levels of actionorientation, it helps in preventing opportunities for potential value-slippages (Lepak et al., 2007). By keeping a focus on a macro-level performance benchmarks as well as micro-level performance metrics of a project/process, it is much easier to capture value and achieve high levels of performance.

\section{DISCUSSION AND IMPLICATIONS}

In answering the study's first question, we found several HRM practices that support various interlocking elements value creation and capture in a firm's business model. HRM practices that support value creation were: client-centric values, learning and development and work design and HRM practices that support value creation were: efficient training, focused hiring, process-focussed HRM and project-focused performance management. In answering the study's second research question, we have demonstrated how various HRM practices interact and complement the achievement of various interlocking elements in a firm's business model. Firms in the IT industry invested in resources and capabilities that were valuable, rare, and inimitable and organised in a socially complex way. The actual nature and extent of these activities varied depending on the firms' strategies, client demands and the nature of work undertaken. Figure 3 demonstrates the multiple influences of internal and external factors on value creation and capture activities, as well as the interactions between the same. For example, through the specific task and process knowledge obtained through quality-oriented approach to HRM, the recruitment and selection requirements for each job focused on acquiring resources in a narrow range of knowledge and skills such as hiring recent college graduates. The above profiles of resources were then provided knowledge and skills training through firms' internal training infrastructures. Similarly, by using specific effort and knowledge estimation techniques embedded in quality frameworks such as that of 'People Capability Maturity' models, focused knowledge and skill development, workflow control, performance and rewards management practices were shaped for both graduates and lateral hires. By standardizing tasks through quality management systems and processes and providing highly context-specific learning and development to various groups of employees, firms were been able to institutionalise key performance expectations and the metrics necessary for value creation and realisation through such tasks and activities (Malik et al., 2012). These metrics were shared extensively within the workgroups through performance dashboards, group meetings, and published through enterprise resource software platforms as key 'critical to quality' tasks and performance benchmarks. Employees were very clear about the key activities that lead to 
value-add. By investing in focused training practices, firms were also able to 'manage the pyramid' and deliver value creation and capture through specific HRM practices.

\section{Resource Based View of Firm}

Overall, our findings support the primacy of two overarching resource-based approaches: a quality- and metric-oriented approach to HRM and skills-development that underpins value creation and capture in a firm's business model. This would suggest that firms employ complementing approaches to value creation and realisation (i.e. a business model approach). Our findings further suggest the dominance of a business model that exploits the existing resources and knowledge architectures for efficiency seeking motives, whilst also paying attention to the latent and expressed needs of its client constituencies. Managers in the Indian IT industry can focus on the seven sets of HRM practices that impact on value creation and capture. Thus managers in the Indian IT industry should pay attention to the complementarities that exist between the two human resource bases of value creation and capture. Although this dominant approach has fuelled the growth in the last three decades in the Indian IT industry, we argue that future growth will be fuelled not through efficiencydriven incremental innovations, but through disruptive innovations caused by recent technological changes such as those occurring in social media, big data analytics, mobility devices and cloud computing. All this would mean reprogramming the Indian IT leaders' mindset and supporting HRM practices that will support a business model change from efficiency and exploitation to experimentation and exploration focus. This would necessitate further theoretical exploration of the key resources that HRM practices would need to develop that will support experimentation, adaptation and generation of new ideas for a firm's business model. Future studies should focus on how new knowledge creation and appropriation occurs through HRM practices in this context.

We acknowledge that there are several limitations of this study. These include a single sector, cross-sectional qualitative case study design that cannot be generalised to other contexts. Further, longitudinal, multi-method, multi-wave and ex-post facto survey designs focusing on a range of contexts is much needed to advance future scholarship in this emerging area of value creating and realising HRM practices to support a firm's business model.

\section{REFERENCES}

Abdelkafi, N., Makhotin, S., \& Posselt, T. (2013). Business model innovations for electric mobility-what can be learned from existing business model patterns?. International Journal of Innovation Management, 17(01).

Baden-Fuller, C., \& Morgan, M. S. (2010). Business models as models. Long Range Planning, 43(2), 156-171.

Barney, J. (1991). Firm resources and sustained competitive advantage. Journal of Management, 17(1), 99-120.

Becker, B. E., \& Huselid, M. A. (2006). Strategic human resources management: where do we go from here? Journal of Management, 32(6), 898-925. 
Boxall, P. (1998). Achieving competitive advantage through human resource strategy: towards a theory of industry dynamics. Human Resource Management Review, 8(3), 265-288.

Budhwar, P. and Bhatnagar, J. (2009) The changing face of people management in India. London: Routledge.

Budhwar, P., Luthar, H. K., \& Bhatnagar, J. (2006a). The dynamics of HRM systems in Indian BPO firms. Journal of Labor Research, 27 (3), 339-360

Budhwar, P. S., \& Varma, A. (2011). Emerging HR management trends in India and the way forward. Organizational Dynamics, 40 (4), 317-325.

Budhwar, P., Varma, A., Singh, V., \& Dhar, R. (2006b). HRM systems of Indian call centres: An exploratory study. The International Journal of Human Resource Management, 17 (5), 881-897.

Budhwar, P. and Varma, A. (2011) Emerging HR management trends in India and the way forward. Organizational Dynamics, 40: 317-325.

Buller, P. F., \& McEvoy, G. M. (2012). Strategy, human resource management and performance: Sharpening line of sight. Human resource management review, 22(1), 43-56.

Casadesus-Masanell, R., \& Ricart, J. E. (2010). From strategy to business models and onto tactics. Long range planning, 43(2), 195-215.

Coombes, P. H., \& Nicholson, J. D. (2013). Business models and their relationship with marketing: A systematic literature review. Industrial Marketing Management, 42(5), 656-664.

Cretchley, J., Rooney, D., \& Gallois, C. (2010).Mapping a 40-year history with Leximancer: Themes and concepts in the journal of cross-cultural psychology, 41(3): 318-328.

Dann, S. (2010). Redefining social marketing with contemporary commercial marketing definitions. Journal of Business Research, 63: 147-153.147-153.

Economic Times. (2007). \$2bn spent for IT/ITeS Co's on training in '07. Retrieved April 2, 2007, from www.economictimes.com

Eisenhardt, K. M. (1989). Building theories from case study research. Academy of Management Review, 14: 532-550.

Global Legal. (2013). Myth\#2: Increased wages in India translate directly to increased costs for US buyers of IT services. Retrieved on 11 March 2014 from www.globallegal.worldpress.com

Gioia, D., Corley, K., \& Hamilton, A. (2012) Seeking qualitative rigor in inductive research: Notes on the Gioia methodology. Organizational Research Methods, 16(1): 15-31.

Grech, M., Horberry, T., \& Smith A. (2002) Human error in maritime operations: Analyses of accident reports using the Leximancer tool. Proceedings of the Human Factors and Ergonomics Society 46th Annual Meeting, Baltimore: Human Factors and Ergonomics Society.

Guest, D. (2011). Human resource management and performance: still searching for some answers. Human Resource Management Journal, Volume 21, Issue 1.

Günzel, F., \& Holm, A. B. (2013). One Size Does Not Fit All-Understanding The Front-End And Back-End Of Business Model Innovation. International Journal of Innovation Management, 17(01).

Johnson, M. W., Christensen, C. C., \& Kagermann, H. (2008). Reinventing your business model. Harvard Business Review, 86(12): 50-59. 
Lepak, D. P., Smith, K. G., \& Taylor, M. S. (2007). Value creation and value capture: a multilevel perspective. Academy of Management Review, 32(1), 180-194.

Liesch, P., Hakanson, L., McGaughey, S. \& Cretchley, J. (2011). The evolution of the international business field: a scientometric investigation of articles published in its premier journal. Scientometrics, 88(1): 17-42.

Malik, A. (2009). Training drivers, competitive strategy and clients' needs: Case studies of three business process outsourcing organisations. Journal of European Industrial Training, 33: 160-177.

Malik, A., \& Rowley, C. (Eds.) (2015). Business models and people management in the Indian IT industry: From people to profits. Abingdon: Routledge.

Malik, A., Sinha, A., \& Blumenfeld, S. (2012). Role of quality management capabilities in developing market-based organisational learning capabilities: Case study evidence from four Indian business process outsourcing firms. Industrial Marketing Management 41(4): 639-648.

Malik, A. (2013). Post-GFC people management challenges: A study of India's information technology sector. Asia Pacific Business Review, 19(2): 230-246

Metropolis, N., Rosenbluth, A.W., Rosenbluth, M.N., Teller, A.H. \& Teller, E. (1953). Equation of state calculations by fast computing machines. Journal of Chemical Physics, 21(6): 1087-1092.

Miles, B. M., \& Huberman, A. M. (1994). Qualitative data analysis: An expanded sourcebook (2nd ed.). Thousand Oaks, CA: Sage.

Morris, M. H., M. Schindehutte, and J. Allen (2005). "The Entrepreneur's Business Model: Toward a Unified Perspective," Journal of Business Research 58(6), 726-735.

O'Connor, A., \& Yamin, S. (2011). Innovation and entrepreneurship: managing the paradox of purpose in business model innovation. International Journal of Learning and Intellectual Capital, 8(3), 239-255.

Osterwalder, A., \& Pigneur, Y. (2005). Clarifying business models: Origins, present, and future of the concept. Communications of the AIS, 16, 1-25.

Osterwalder, A., \& Pigneur, Y. (2010). Business Model Generation: A Handbook For Visionaries, Game Changers, And Challengers. Alexander Osterwalder, Yves.

Pereira, V. \& Anderson, V (2012). A longitudinal examination of HRM in an Human Resources Offshoring (HRO) organization operation from India. Journal of World Business. 47, 2, 223-231.

Pfeffer, J. (1998). The human equation: Building profits by putting people first. Boston, MA: Harvard Business School Press.

Priem, R. L. (2007). A consumer perspective on value creation. Academy of Management Review, 32(1), 219-235.

Roy, S. (2013). Gap between mid-level, freshers' wages is set to widen by 8 times. The Economic Times, December 24, Bangalore ET Bureau. Retrieved on 08 February 2014 from www.articles.economictimes.com

Schnieder, S., \& Speith, S. (2013). Business model innovation: Towards an integrated future research agenda. International Journal of Innovation Management, 17(01), 1-35

Sinha, V. (25 November, 2013). Real salaries of software engineers lowest in 15 years: Credit Suisse. NDTV Profit. Retrieved on 11 March 2014 from www.profit.ndtv.com

Smith, A. E. (2003). Automatic extraction of semantic networks from text using Leximancer. Paper presented at the HLT-NAACL 2003 Human Language Technology Conference of 
the North American Chapter of the Association for Computational Linguistics, Edmonton, Alberta, Canada.

Smith A., \& Humphreys M. (2006). Evaluation of unsupervised semantic mapping of natural language with Leximancer concept mapping. Behaviour Research Methods, 38(2):262-79.

Spieth, P., Tidd, J., Matzler, K., Schneckenberg, D., \& Vanhaverbeke, W. (2013). Special Issue On Business Model Innovation-Editorial Note. International Journal of Innovation Management, 17(01), 1-3

Spieth, P., Schneckenberg, D., \& Ricart, J. E. (2014). Business model innovation-state of the art and future challenges for the field. R\&D Management, 44(3), 237-247.

Teece, D. J. (2010). Business models, business strategy and innovation. Long Range Planning, 43(2-3), 172-194.

Teece, D. J., Pisano, G., \& Schuen, A. (1997). Dynamic capabilities and strategic management. Strategic Management Journal, 18: 509-533.

Van Maanen, J., Sørensen, J. B., \& Mitchell, T. R. (2007). The interplay between theory and method. Academy of Management Review, 32(4): 1145-1154.

Varma, A., Budhwar, P., \& DeNisi, A. (2008). Performance Management Systems around the Globe. London: Routledge.

Wright, P. M., Dunford, B. B., \& Snell, S. A. (2001). Human resources and the resource based view of the firm. Journal of management, 27(6), 701-721.

Wright, P. M., \& McMahan, G. C. (1992). Theoretical perspectives for strategic human resource management. Journal of management, 18(2), 295-320.

Yin, R. (2009). Case study research: Design and methods. London: Sage..

Zott, C., Amit, R., \& Massa, L. (2011). The business model: recent developments and future research. Journal of management, 37(4), 1019-1042.

Zott, C., \& Amit, R. (2013). The business model: A theoretically anchored robust construct for strategic analysis. Strategic Organization, 11(4): 403-411

Table 1: Case descriptions

\begin{tabular}{|l|l|l|l|l|}
\hline $\begin{array}{l}\text { Case } \\
\text { Organisation }\end{array}$ & Location & $\begin{array}{l}\text { Employee } \\
\text { Size* }\end{array}$ & Ownership & Services \\
\hline A & Gurgaon & 26,000 & US-MNC & Business process outsourcing (BPO) \\
\hline B & Mumbai & 1500 & $\begin{array}{l}\text { Joint venture } \\
\text { (India \& US) }\end{array}$ & $\begin{array}{l}\text { BPO \& Knowledge process outsourcing } \\
\text { (KPO) }\end{array}$ \\
\hline C & Gurgaon & 200 & UK-MNC & BPO \\
\hline D & New Delhi & 70 & Indian & BPO \\
\hline E & Bangalore & 35000 & US-MNC & IT-product and software services \\
\hline F & Bangalore & 40000 & Indian MNC & IT-product and software services \\
\hline G & Bangalore & 2700 & US-MNC & IT-product development \\
\hline H & Bangalore & 800 & Indian & IT-software services \\
\hline I & Hyderabad & 150 & US-MNC & IT-product development \\
\hline J & Bangalore & 36 & US-MNC & IT-software services \\
\hline
\end{tabular}

* Approximate employee numbers are stated to maintain confidentiality of the firms

Table 2: Interviewee details 


\begin{tabular}{|l|l|l|l|l|l|l|l|l|}
\hline $\begin{array}{l}\text { Case } \\
\text { Organisation }\end{array}$ & CEO/COO & $\begin{array}{l}\text { HR } \\
\text { Managers }\end{array}$ & $\begin{array}{l}\text { Training } \\
\text { Manager }\end{array}$ & $\begin{array}{l}\text { Project } \\
\text { Manager }\end{array}$ & Quality & Employees & $\begin{array}{l}\text { Business } \\
\text { Development }\end{array}$ & Total \\
\hline A & & 2 & 1 & 3 & 2 & 2 & & 10 \\
\hline B & & 1 & 2 & 2 & 1 & 2 & & 08 \\
\hline C & 1 & 1 & 1 & 2 & 1 & 6 & 1 & 13 \\
\hline D & $1^{*}$ & & & 2 & 1 & 6 & $1^{*}$ & 10 \\
\hline E & & 2 & & 2 & 1 & 1 & & 06 \\
\hline F & & 1 & 1 & 3 & 1 & & & 06 \\
\hline G & & 2 & 1 & 1 & 1 & 1 & & 06 \\
\hline H & & 2 & & 2 & 1 & 1 & & 06 \\
\hline I & 1 & 2 & & 3 & & 2 & & 08 \\
\hline J & $1^{*}$ & 1 & & 2 & & 3 & $1^{*}$ & 07 \\
\hline
\end{tabular}

* Note: The CEO/COO was also the business development manager in these small-sized firms

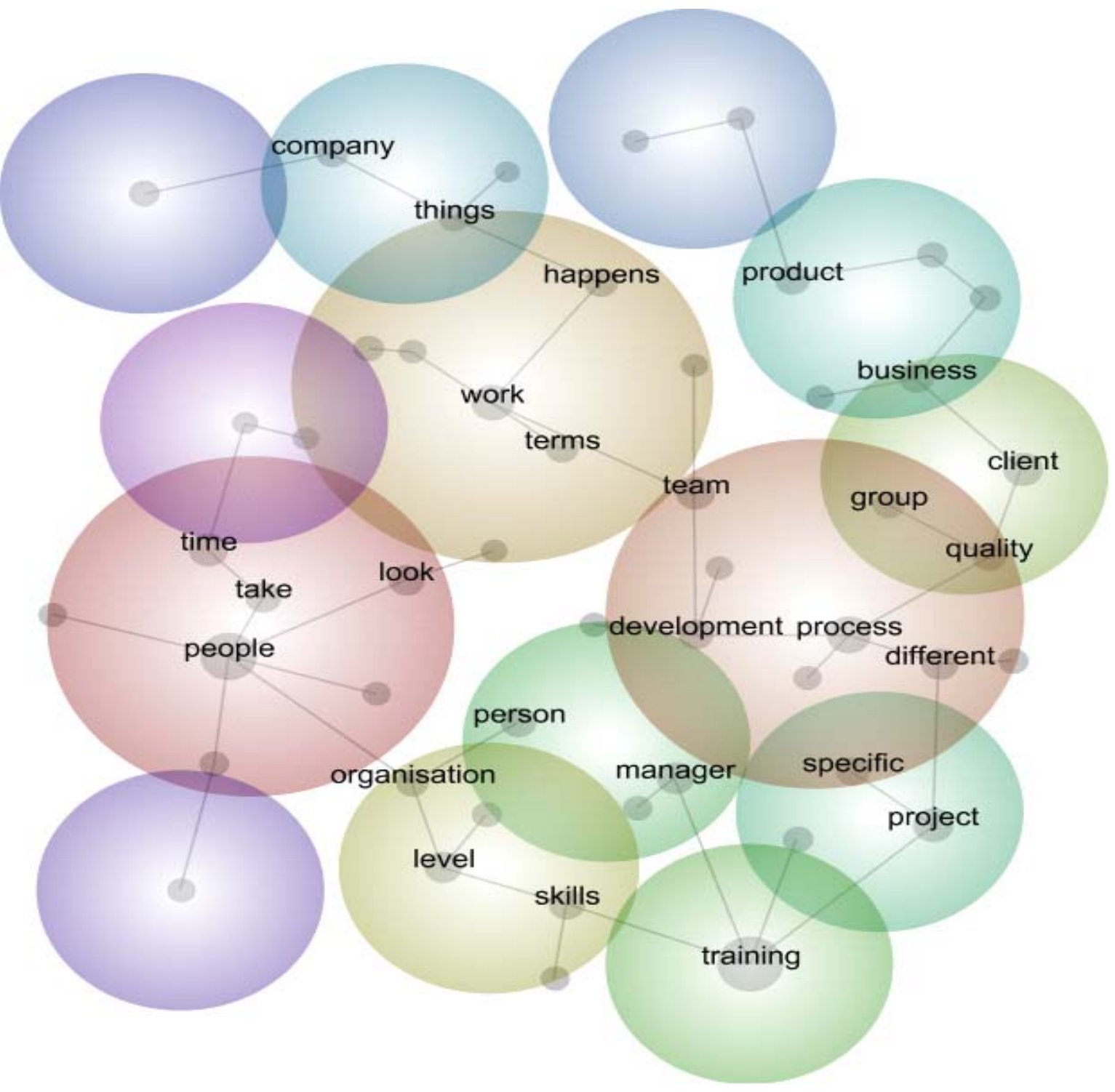


Figure 1: A visual Leximancer Map of the key concepts and themes

FIGURE 2

Data Structure

Table 3 HR practices supporting value creation

\begin{tabular}{|l|l|}
\hline $\begin{array}{l}\text { Stages and } \\
\text { Processes of } \\
\text { creating value } \\
\text { through HRM }\end{array}$ & Examples \\
\hline $\begin{array}{l}\text { Client-centric } \\
\text { values/culture }\end{array}$ & $\begin{array}{l}\text { You see if the client doesn't have a very structured accounting procedure, we try and } \\
\text { use this [application and tools] and enhance their efficiency.... Though we deploy it } \\
\text { here we also deploy it at the clients' ends..... If the client already has another } \\
\text { automated application like an ERP ...we carry out some integration to adapt to it. } \\
\text { Finance Process Manager, Organisation D }\end{array}$ \\
\hline Client needs & $\begin{array}{l}\text { Our solutions strategy is that we understand customers' needs and then see what } \\
\text { solutions we might provide, whilst also keeping in mind our resources and capabilities. } \\
\text { Not as if one size fits everyone. It won't be ever that in a vertical say F\&A all clients will } \\
\text { get a cut and copy solution. It is highly contextualized solutions that are offered. As I } \\
\text { am saying this, you would realize that so much in training is demanded at all levels in } \\
\text { the process. HR manager, Organisation A }\end{array}$ \\
\hline Customer gains & $\begin{array}{l}\text { See once a new client comes on board..., there is a core team that is identified: } \\
\text { from operations, business development, and training. This core team goes to } \\
\text { the client site, spends time there between 4-12 weeks. They have a very clear } \\
\text { and defined agenda, and they work with the people out there.... As they start } \\
\text { working, they keep on creating side by side a ...note of processes, capturing } \\
\text { sub-processes. ...so they break the processes down into smaller parts, into sub- } \\
\text { processes. }\end{array}$ \\
\hline $\begin{array}{l}\text { From the operations side, it's a matter of improving operational efficiencies, } \\
\text { how do we pass the benefits realized through SS and lean to the clients. } \\
\text { Manager Content Development - Organisation A }\end{array}$ \\
\hline
\end{tabular}




\begin{tabular}{|c|c|}
\hline Client confidence & $\begin{array}{l}\text { Business development has a front end and a back end; they identify an area but } \\
\text { to build on to an area the back end team looks at the solutions for that } \\
\text { business. Sometimes some of the clients request a dedicated bay no sharing, } \\
\text { then the solutioning team would work on a solution. As most terminals are } \\
\text { used for three shifts, so if a client insists on exclusive infrastructure then the } \\
\text { costs would go up and the benefits and trade-offs are explained to the client. } \\
\text { Infrastructure and occupancy is a major cost item, training costs are fixed as a } \\
\text { percentage of the contract Six Sigma Black Belt - Organisation A } \\
\text {...we operate is on a wing-to-wing basis here. A wing-to-wing is basically the } \\
\text { entire gamut of work for a client or the overall process. So a client may start } \\
\text { from a basic process, but today we may be having more complex processes for } \\
\text { the same client. So if you see the importance of training, everything is different } \\
\text { here and people are different too. VP Insurance Processes - Organisation A }\end{array}$ \\
\hline $\begin{array}{l}\text { Openness to } \\
\text { change }\end{array}$ & $\begin{array}{l}\text { So what happens is that when a business comes up and says I am running this } \\
\text { problem, at that time when we do the solutions architecture that might lead to } \\
\text { some changes in the processes at their end, their training thinking and } \\
\text { methodologies and deliveries. So we make some models upfront and show } \\
\text { them here is what you need or want to do or if you are willing to go down this } \\
\text { path. That's the package we sell. We tell this upfront. We accept a project and } \\
\text { then we take time to deliver. That's the package we try to push upfront and go } \\
\text { ahead with its development. If they are willing to sign the dotted line then we } \\
\text { go forward. Manager Content Development - Organisation A }\end{array}$ \\
\hline $\begin{array}{l}\text { Learning and } \\
\text { Development } \\
\text { Technical } \\
\text { knowledge }\end{array}$ & $\begin{array}{l}\text { I think at least I can say } 80 \% \text { to } 90 \% \text { would be technical skills soft skills is } 10 \% \text {. } \\
\text { Head - Human Resources - Organisation B } \\
\text { Probably it is more of non-technical interventions. And certain common } \\
\text { technical skills are required, like project management and understanding } \\
\text { Organisation G. Understanding the product line, product growth. Head - } \\
\text { Learning and Development - Organisation G }\end{array}$ \\
\hline $\begin{array}{l}\text { Training and } \\
\text { development }\end{array}$ & $\begin{array}{l}\text { Organisation } G \text { university as of today has about } 7000 \text { courses, and we are tying } \\
\text { up with various providers who offer a large number of courses via e-learning } \\
\text { mode. We have two or three different learning management systems within } \\
\text { Organisation } G \text { which we can access. One is to do with external courses } \\
\text { another one is to do with the internal course is published and there are large } \\
\text { number of courses that are available on multiple modules to choose depending } \\
\text { upon if they are for different locations and products. Head - Learning and } \\
\text { Development - Organisation G } \\
\text { So they'll (fresh hires) go through } 31 \frac{1}{2} \text { months (of training) ... so a lot of } \\
\text { companies which have this kind of recruitment model needs to have an entry } \\
\text { programme. ... may be } 3 \text { months or } 3 \text { weeks... } 15 \text { weeks or, so we have for } \\
\text { them and from which we start from the basics and then it takes some time till } \\
\text { [they reach] certain level ....we teach them different specific technologies ...VP } \\
\text { Learning \& Development Organisation F }\end{array}$ \\
\hline Product/Project & $\begin{array}{l}\text { We start with the product training telling them what are the products we are } \\
\text { selling and what are their main features. What are product specifications, and }\end{array}$ \\
\hline
\end{tabular}




\begin{tabular}{|c|c|}
\hline Specific training & $\begin{array}{l}\text { how do they need to go about it. Once we are through with the product } \\
\text { training, the next thing is what we need to do as part of the job, i.e. calls. HR } \\
\text { Manager Organisation B. } \\
\text { The response that we got that we were able to explain the product much } \\
\text { better - we were doing a lot of product training. At the end of the day you } \\
\text { should understand the requirements of the customers what they want - it } \\
\text { should not just be selling a product, it should be a quality sale. Voice Process } \\
\text { Manager- Organisation B } \\
\text { Even in voice they join us and go through their induction and they go through } \\
\text { about the organisation and are given an overview of quality and other } \\
\text { functions and then they are handed over to our voice and accent trainer, to } \\
\text { neutralize their accents. Then they are put on the process training, and learn } \\
\text { about the process knowledge, which software they have to work on. We have } \\
\text { some simulation exercise for them to familiarize on the software, the they have } \\
\text { to actually undergo assessments and finally they have to be certified by a } \\
\text { quality person, who is part of our quality team as well as one person from our } \\
\text { external client before they hit the floor. If they are not found fit then they } \\
\text { would again go through the training process. VP Insurance Process - } \\
\text { Organisation A }\end{array}$ \\
\hline $\begin{array}{l}\text { Assessment and } \\
\text { certification of } \\
\text { training }\end{array}$ & $\begin{array}{l}\text { During the process training, what we did was we built in stringent tests and } \\
\text { examinations. Because of building these tests and examinations we ensure that } \\
\text { the day they are supposed to pass out from here they are not allowed to } \\
\text { actually go and work until they have successfully passed the test. } \\
\text { Yes, it is a very stringent evaluation of their learning. We only allow them to hit } \\
\text { the shopfloor when they have passed the test. They are supposed to pass each } \\
\text { of these exams, as if they don't, then even a small error can have an impact on } \\
\text { the end customer. So, it may take three weeks, four weeks or more, but we do } \\
\text { not allow any person to work before passing the exams. }\end{array}$ \\
\hline \multicolumn{2}{|l|}{ Work Design } \\
\hline Process discipline & $\begin{array}{l}\text { I think we are projecting ourselves as a business that is driven by six sigma, very strong } \\
\text { in process excellence, so our biggest differentiator is process excellence... That's why } \\
\text { training becomes more extensive, our people need to understand the important of } \\
\text { quality and the processes. Each phase has an opportunity to be fulfilled and training } \\
\text { plays a role at each stage - its not just hiring the right people its also upskilling the } \\
\text { resources in different areas - professional skills and leadership skills development. Six } \\
\text { Sigma Expert- Organisation A } \\
\text { Sometimes you find that the process that we have which are official but not exactly } \\
\text { right, so we try to customise, we actually build some of the processes. Head of Quality- } \\
\text { Organisation G }\end{array}$ \\
\hline $\begin{array}{l}\text { Value stream } \\
\text { mapping }\end{array}$ & $\begin{array}{l}\text { We are also now into reengineering offering, wherein we help the customer } \\
\text { streamline the processes even before we initiate the transition, this becomes } \\
\text { part of the solutions and helps in streamlining the migration [of projects]....the } \\
\text { customer sees the maximum benefit as the process is simplified before } \\
\text { transition, second the value to the customer is immense, you end up giving value } \\
\text { add to the customer; this is our differentiator. ...reduce the non-value add. } \\
\text { Process manager- Organisation A }\end{array}$ \\
\hline
\end{tabular}




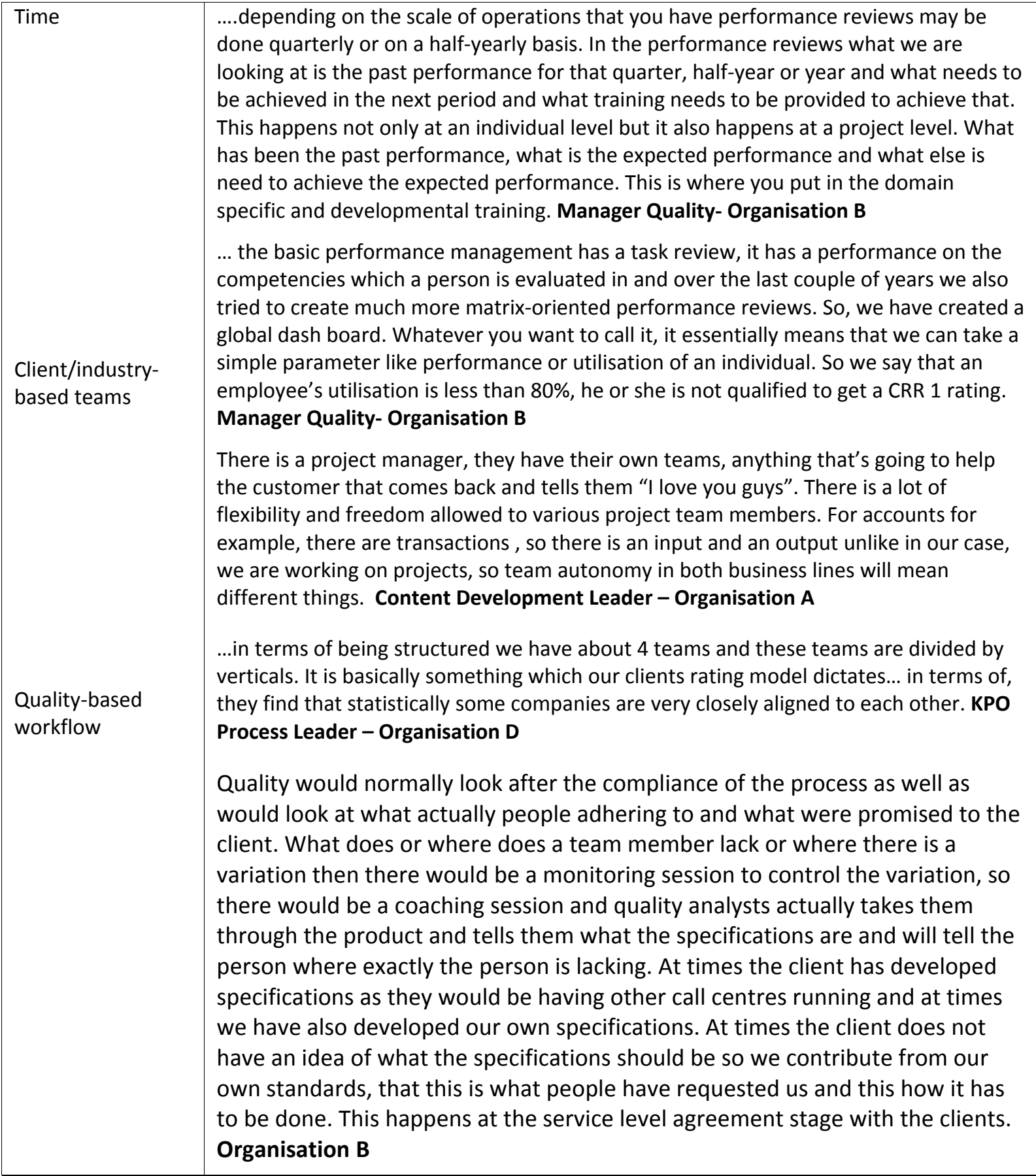

TABLE: 4 HR practices supporting value capture

\begin{tabular}{|c|c|}
\hline $\begin{array}{l}\text { Stages and } \\
\text { Processes of value } \\
\text { realisation }\end{array}$ & Examples \\
\hline Efficient training & \\
\hline $\begin{array}{l}\text { Quality } \\
\text { management skills }\end{array}$ & $\begin{array}{l}\text { Our training currently is more focused on processes, process knowledge, from } \\
\text { the client perspective and the quality and now that we have started off into the } \\
\text { growth phase and that we will be looking into the development of } \\
\text { people....People capability maturity model (PCMM), if you look at a BPO and it } \\
\text { follows the entire process of the model, then that is the most effective way of }\end{array}$ \\
\hline
\end{tabular}




\begin{tabular}{|c|c|}
\hline & $\begin{array}{l}\text { people management in a BPO. So, the on the basis of which stage [of PCMM] } \\
\text { your processes are at...the kind of trainings devised are different. ...if you are at } \\
\text { the first level [of PCMM], you know where you have no control over the project, } \\
\text { there the kind of training needs and the kinds of training plans ...are absolutely } \\
\text { different from when you move on to the last stage, where everything is in your } \\
\text { control and where you should start bringing in continuous improvement projects } \\
\text { and more of developmental training. Quality Manager- Organisation C } \\
\text { We...adapted the CMM framework which means you need to have checklist or a } \\
\text { process or a format to follow for every state[of the development cycle] which is } \\
\text { almost like an internal best practice sharing. HR Manager, Organisation F } \\
\text { Yes, we define the process, we talk to them [business groups], we understand } \\
\text { their business processes, we document that, we establish that processes, we see } \\
\text { that all the rules have been followed, then we take the measurement, and we } \\
\text { keep checking assessments and ...and improve from there. Manager Quality, } \\
\text { Organisation G }\end{array}$ \\
\hline $\begin{array}{l}\text { Domain-specific } \\
\text { training }\end{array}$ & $\begin{array}{l}\text { You have to have domain knowledge experts who can understand customer needs and } \\
\text { design solutions. It cannot happen that we don't have domain expertise and we try to } \\
\text { offer solutions to clients. So, obviously training as an opportunity is present at all these } \\
\text { levels in the process. HR manager, Organisation A }\end{array}$ \\
\hline $\begin{array}{l}\text { Client-specific } \\
\text { training } \\
\text { Efficiency }\end{array}$ & $\begin{array}{l}\text {...what happens is that specialisation would only happen if, only when they would be } \\
\text { able to deliver numbers, only when they get on the floor, thy pick up one liners from } \\
\text { their colleagues and that's when they learn from their colleagues- adapt to the } \\
\text { customers etc, that might take some time. This is how the entire training is organised. } \\
\text { Before we start on the training there is a requirement that comes from the clients. } \\
\text { Organisation B } \\
\text {...we have set up to take advantage of the highly skilled manpower available, which is } \\
\text { available at a much lower cost compared to US, an efficiency, work culture, ethics and } \\
\text { commitment, and stuff like that. That's the reason why we have come. HR Manager- } \\
\text { Organisation H }\end{array}$ \\
\hline \multicolumn{2}{|l|}{ Focussed Hiring } \\
\hline $\begin{array}{l}\text { Graduate vs } \\
\text { experienced hires }\end{array}$ & $\begin{array}{l}\text {...we keep projecting that we invest in our employees so...that is the feeling that } \\
\text { we do internally ....that it is a strategy. But is that the reason why we are } \\
\text { recruiting people with lesser experience, no that's not true. The strategy really is } \\
\text { managing the cost structure, but in order take may it work you have to invest, HR } \\
\text { Manager- Organisation F } \\
\text {...the only ratio which is increasing in last couple of years is number of campus } \\
\text { hires as a \% of people we take in every year ....[it] has shot up significantly. ...so } \\
\text { what it means is while it helps us in reducing the cost it also means that how we } \\
\text { deploy these people, how we train them...the entire cycle. HR Manager- } \\
\text { Organisation E } \\
\text { Organisation X has traditionally [been] known to hire a lot of interns and college } \\
\text { graduates. HR Manager- Organisation G }\end{array}$ \\
\hline $\begin{array}{l}\text { Low- vs high-end } \\
\text { qualifications }\end{array}$ & $\begin{array}{l}\text { Organisation G's model [is to] hire people with requisite amount of experience and the } \\
\text { focus is on their trainability, which is mostly on the job. There is a certain amount of } \\
\text { slack built into the resourcing model to allow for the training and downtime. The } \\
\text { productivity of Organisation G is relatively less than AMD ...their [AMD's] average years } \\
\text { of experience will be 6-7 [years] as compared to Organisation G's 2-2.5[years]. This } \\
\text { slack is built into the costing. It's a leader and follower strategy. As a leader you have }\end{array}$ \\
\hline
\end{tabular}




\begin{tabular}{|c|c|}
\hline Composition & $\begin{array}{l}\text { time to build that slack. It's a very carefully thought out strategy. If you are leading the } \\
\text { technology, then you are not competing against somebody, you are not really in a rush } \\
\text { to complete a project- this strategy has worked really well for Organisation G globally, } \\
\text { only recently has AMD started to take on board the challenge. HR Manager, } \\
\text { Organisation G } \\
\text {...see that's the business model. Business model is saying how you leverage ...the } \\
\text { cost structure ...at the lower level, you have to manage the cost structure ...for } \\
\text { instance, the competing company might have people with } 5 \text { years' experience } \\
\text { doing a particular job and here we may have somebody with } 2 \text { years' experience. } \\
\text {... so the driver is the business model so once you have the business model in } \\
\text { order to make it successful you obviously have to invest a lot in the training ... } \\
\text { and so that investment [in training] is also good for us and ...for people, so } \\
\text { people appreciate that the kind of responsibility I can get in } 5 \text { years, if I can get in } \\
2 \text { years, with necessary support then people are happy. Vice-President Training } \\
\text { - Organisation F }\end{array}$ \\
\hline \multicolumn{2}{|l|}{$\begin{array}{l}\text { Process-focussed } \\
\text { HRM }\end{array}$} \\
\hline Focused training & $\begin{array}{l}\text { We have a half-yearly appraisal system whereby the quality team tracks the production } \\
\text { as well as the quality of the processes. Then we decide that this particular resource } \\
\text { requires training in such and such area. Subject matter experts organise one-to-one } \\
\text { meetings with the team members and then we decide what the problem is and how we } \\
\text { can improve upon it. In voice we have CTQ (Critical to quality) metrics: invoice } \\
\text { numbers, date, amount, etc. If person has to process an invoice he/she has to pass } \\
\text { through at least 6-7 CTQ fields. Back Office Team Leader- Organisation B } \\
\text { It's the quality assurance person and the line manager who work together on every } \\
\text { team member. ....assessing the quality of the process but each of them are judging it on } \\
\text { different parameters and each sample about } 10 \% \text { of the entire transactions. QA team } \\
\text { are not only looking at the quality metrics but they are also looking at the efficiencies } \\
\text { for that process- the time taken to process that transaction and tracking their daily } \\
\text { productivity etc. Back Office Team Leader- Organisation B }\end{array}$ \\
\hline $\begin{array}{l}\text { Cost and error } \\
\text { reduction }\end{array}$ & $\begin{array}{l}\text { We follow the Six Sigma methodology; we would have people trained in Six Sigma who } \\
\text { would then define the quality methods and the people we have hired externally or } \\
\text { have been developed internally as quality analysts would not only look at compliance } \\
\text { issues but also look at the analysis of these reports... performance measures and look } \\
\text { at if they are only internally trained on Six Sigma by their manager... Mostly it is in- } \\
\text { house but we do have people who are trained and certified externally. Manager } \\
\text { Quality- Organisation B }\end{array}$ \\
\hline Process excellence & $\begin{array}{l}\text { Accuracy again is based on SS, which talks of number of errors and defects per million. } \\
\text { This is again defined at the client level- what levels of accuracy they want, they would } \\
\text { say we want a } 3 \text { level or a } 4 \text { level SS, so we work accordingly. It also depends from } \\
\text { industry to industry, for example, the airline industry cannot operate on a low six sigma } \\
\text { - they may operate on a SS level of } 12 \text {, six may not be good enough for them. Six is } \\
\text { good for us, but we typically operate on the nature of the process, complexity of the } \\
\text { process and based on what the client requirements are. Six Sigma Manager, } \\
\text { Organisation A } \\
\text { We use a proprietary tool; it's a kind of sales force automation. Everything is captured. } \\
\text { It's a beautiful system in the sense that I can see the entire transaction record as well as } \\
\text { day to day process, day to day for any client or any requirement or every sales guide, } \\
\text { ever recruiting guide, everything is available, as a cross-sectional slice, down the middle } \\
\text { slice, just slice and dice and get analytical. Country Manager- Organisation J }\end{array}$ \\
\hline
\end{tabular}




\begin{tabular}{|c|c|}
\hline & $\begin{array}{l}\text {...given that the workforce is young and relatively less experienced, they are trained on } \\
\text { Organisation G specific proprietary tools, systems, and technologies that they become } \\
\text { so much Organisation G-ized that they are unaware of what the industry standard or } \\
\text { how the industry could utilise their skills more effectively. ...given the highly } \\
\text { Organisation G-specific environment that they work in. The tools and standards are so } \\
\text { customised to Organisation G that they may not be usable for other companies in the } \\
\text { microprocessor technologies. Level of customisation is exceptionally high. For example, } \\
\text { Organisation G was using PeopleSoft's version 7, when they wanted to move to the } \\
\text { next version, Organisation G asked for close to } 1500 \text { customisation requests that it } \\
\text { became unviable for PeopleSoft to deliver the customisations to Organisation G. You } \\
\text { can imagine what happens in the product development space. That is how the hiring } \\
\text { strategy works: right qualification, aptitude and skills and then mould them into } \\
\text { Organisation G-specific requirements. HR Director - Organisation G } \\
\text { It [quality] is considered very important because the penalty, which we pay is } \\
\text { very high. If we miss a deadline due to bugs or mistakes...we will be in severe } \\
\text { trouble. Sometimes we may lose a million dollars because it [performance } \\
\text { quality] is linked to the ...maintenance contracts. ...So we consider quality very } \\
\text { seriously during our development process ... They [software developers] do a } \\
\text { thorough unit testing .... After that the developer is satisfied, and he sends it for } \\
\text { peer review. Another developer will review his work and he will give his } \\
\text { comments. After that it is sent to the QA team. They will test it thoroughly and } \\
\text { once everybody is satisfied then only it is going to Atlanta. Even there, there is } \\
\text { acceptance testing. They should be satisfied and only then it is deployed in the } \\
\text { client site. Project Manager- Organisation I }\end{array}$ \\
\hline \multicolumn{2}{|l|}{$\begin{array}{l}\text { Project-based } \\
\text { performance } \\
\text { management }\end{array}$} \\
\hline Happen & $\begin{array}{l}\text { So, this is more of a value-added service. So you see a lot of improvisation happens, } \\
\text { and improvisation can only happen if you are constantly on it. Because of this } \\
\text { change they realised that there was another department that was facing a } \\
\text { similar problem, so they modified at their end too. All this is managed by } \\
\text { training. See identifying a new idea is done by people in quality, they then } \\
\text { break it down into smaller parts and bring about process improvements, once } \\
\text { this is done then it becomes the responsibility of the trainers to make sure this } \\
\text { knowledge is disseminated. Six Sigma Manager, Organisation A }\end{array}$ \\
\hline Timelines & $\begin{array}{l}\text {... depending on the scale of operations that you have performance reviews may } \\
\text { be done quarterly or on a half-yearly basis. In the performance reviews what } \\
\text { we are looking at is the past performance for that quarter, half-year or year and } \\
\text { what needs to be achieved in the next period and what training needs to be } \\
\text { provided to achieve that. This happens not only at an individual level but it also } \\
\text { happens at a project level. What has been the past performance, what is the } \\
\text { expected performance and what else is need to achieve the expected } \\
\text { performance. This is where you put in the domain specific and developmental } \\
\text { training. Manager Quality- Organisation B }\end{array}$ \\
\hline $\begin{array}{l}\text { Project } \\
\text { specifications }\end{array}$ & $\begin{array}{l}\text { Typically integration processes is very long and lasts for six months or so. There } \\
\text { are different periods where they have to attend different training there are } \\
\text { different recommended path. Typically what has happened over the years } \\
\text { every business group has built their own curriculum for new hires, which } \\
\text { includes certain corporate processes as well as their own business group }\end{array}$ \\
\hline
\end{tabular}




\begin{tabular}{|l|l|}
\hline Quality training & $\begin{array}{l}\text { activities- project specific paths. Head- Learning and Development } \\
\text { Organisation G } \\
\text { Quality training talks about process, talks about policies, ...how do you use the } \\
\text { process, its templates and how do you go about ...doing all these things,... } \\
\text { indeed for doing all these things ...you document, you collect data, you } \\
\text { measure, you find out within the specified bandwidth is there any variation. } \\
\text { Quality Manager- Organisation } \mathbf{H}\end{array}$ \\
$\begin{array}{l}\text { The other aspect of quality training is continuity management because there } \\
\text { are a huge amount of artefacts, data gets captured and there will be stored } \\
\text { properly, detailed properly, so configuration management is a very important } \\
\text { aspect. So there is whole lot of process training which are subject specific, plus } \\
\text { of course CMM awareness what is CMMI different models are there. How they } \\
\text { are going to? How do we access project training with CMM level? What are the } \\
\text { different technologies? Those kind of awareness training in-depth training are } \\
\text { provided. Head- Quality Organisation F }\end{array}$ \\
\hline Lean six sigma & $\begin{array}{l}\text { This is basically an added-value activity. See, at the end of the day, we are } \\
\text { looking at making our lives simple. If things are done well, the chances of error } \\
\text { are less and my accuracy is going to be higher and thus the productivity will go } \\
\text { up. At the client end there will be satisfaction. Six Sigma Manager, } \\
\text { Organisation A }\end{array}$ \\
\hline
\end{tabular}

FIGURE 3: HRM Practices Supporting Value creation and Value Realisation- Through RBV 